\title{
KEDUDUKAN PARA PIHAK DALAM PERJANJIAN KERJASAMA OPERASIONAL PENGEMBANGAN LAHAN PERUMAHAN DAN IMPLIKASINYA TERHADAPHAK PENGELOLAAN LAHAN
}

\author{
Galuh Sawitri, Nanik Tri Hastuti \\ Program Studi Magister Kenotariatan, \\ Fakultas Hukum, Universitas Diponegoro
}

\begin{abstract}
The unity of PT Pradipta Ratnapratala as the owner of the asset with PT Citra Mitra Properti (Ciputra Group) as investor in the Land Development Cooperation Agreement gave birth to a new business entity entity by the parties named "Citra Pradipta KSO".. The formulation of issues that can be stated is the legal standing of the parties in the Cooperation of Cooperation Agreement / KSO of Land Development, how the implications of the legal status of the parties to the right of land management and whether efforts can be made to the rights and obligations of the parties in the operational cooperation agreement to be balanced and equivalent. The research used empirical juridical approach method with qualitative data analysis. The result of this research is the position of the parties in the Cooperation Agreement of Land Development Cooperation, namely PT Pradipta Ratnapratala as the holder of the land of cooperation / as the owner of the asset tends to passive, which then affects the loss of PT Pradipta Ratnapratala's right as the owner of the rightful owner or the right land of cooperation land, to be involved in the implementation process of housing project development. Efforts that can be made is to improve and / or add clauses in the agreement and include the owner of the asset in the operational activities of land development, although in practice the authority will be given with certain limitations.
\end{abstract}

Keywords : Cooperation Agreement, Land Development, Land Management

\begin{abstract}
Abstrak
Bersatunya PT Pradipta Ratnapratala selaku pemilik asset dengan PT Citra Mitra Properti (Ciputra Grup) selaku investor dalam Perjanjian Kerjasama Pengembangan Lahan melahirkan sebuah entitas pelaku usaha baru yang oleh para pihak diberi nama "Citra Pradipta KSO”. Rumusan masalah yang dapat dikemukakan adalah kedudukan hukum para pihak dalam Perjanjian Kerjasama Operasional/ KSO Pengembangan Lahan, bagaimana implikasi dari kedudukan hukum para pihak tersebut terhadap hak pengelolaan lahan serta apakah upaya yang dapat dilakukan agar hak dan kewajiban para pihak dalam perjanjian kerjasama operasional menjadi seimbang dan setara. Penelitian menggunakan metode pendekatan yuridis empiris dengan analisa data kualitatif.Hasil penelitian ini adalah kedudukan para pihak dalam Perjanjian Kerjasama Operasional Pengembangan Lahan yaitu pihak PT Pradipta Ratnapratala selaku pemegang hak atas tanah lahan kerjasama/selaku pemilik asset cendrung pasif, yang kemudian berdampak pada hilangnya hak PT Pradipta Ratnapratala selaku pemilik asset atau pemegang hak yang sah terhadap tanah lahan kerjasama, untuk ikut terlibat pada proses pelaksanaan pembangunan proyek perumahan. Upaya yang dapat dilakukan adalah memperbaiki dan/atau menambahkan klausul-klausul dalam perjanjiandan mengikut sertakan pihak pemilik asset dalam kegiatan operasional pengembangan lahan, walaupun dalam pelaksanaannya kewenangan tersebut akan diberikan dengan batasan tertentu .
\end{abstract}

Kata Kunci: Perjanjian Kerjasama Operasional, Pengembangan Lahan, Pengelolaan Lahan 


\section{A. Pendahuluan}

Kerjasama Operasi/KSO merupakan simbiosis mutualisme dimana para pihak yang bekerjasama saling melengkapi kekurangan masing-masing, memiliki aset tetapi tidak memiliki modal usaha/kapital yang cukup untuk mengembangkan aset tersebut tentu tidak dapat menjadikan aset tersebut sebagai sumber pemasukan finansial bagi pemiliknya, sedangkan di sisi lain ada pihak yang memiliki modal/kapital yang cukup besar akan tetapi tidak mempunyai lahan usaha yang dapat dikembangkan, keadaan ini yang kemudian dinilai sebagai sebuah persatuan yang saling menguntungkan.

Bersatunya PT Pradipta Ratnapratala selaku pemilik aset dan PT Citra Mitra Properti (Ciputra Grup) selaku investor dalam Perjanjian Kerjasama Pengembangan Lahan tersebut melahirkan sebuah entitas pelaku usaha baru yang oleh para pihak diberi nama "Citra Pradipta KSO”. Selanjutnya dengan dibuat dan ditandatanganinya kuasa menjual sebagai tindak lanjut dari dibuat dan ditandatanganinya Perjanjian Kerjasama Pengembangan Lahan tersebut maka hak pengelolaan tanah beralih dari PT Pradipta Ratnapratala kepada PT Citra Mitra Properti tanpa perlu dilaksanakan pengalihan hak terhadap lahan tanah komplek perumahan Bumi Mutiara Wanayasa.

Dari penjabaran di atas sekilas dapat dilihat bahwa sebuah badan usaha kerjasama mempunyai karakteristik tersendiri yaitu antara lain adalah hak dan kewajibannya disamakan dengan hak dan kewajiban yang dikenakan kepada badan usaha berbentuk perseroan terbatas, kegiatan usaha pengembangan lahan dilaksanakan tanpa perlu terlebih dahulu dilakukan pengalihan hak kepemilikan aset, pendiriannya tidak memerlukan pengesahan/persetujuan dari Departemen/Kementerian Hukum dan Hak Asasi Manusia dan faktor lain yang juga krusial yaitu bahwa umur sebuah badan usaha kerjasama adalah sebagaimana telah diperjanjikan oleh para pihak dalam perjanjian kerjasama atau selama proyek masih berlangsung, dan untuk pengakhiran/pembubarannya sebuah badan usaha kerjasama tidak juga perlu melakukan tahapan-tahapan pengakhiran/pembubaran sebagaimana yang wajib dilaksanakan oleh sebuah badan usaha berbentuk badan hukum.

Rumusan masalah yang dikemukakan dalam penelitian ini adalah kedudukan hukum para pihak dalam Perjanjian Kerjasama Operasional/KSOPengembangan Lahan, bagaimana implikasi dari kedudukan hukum para pihak tersebut terhadap hak pengelolaan lahan kerjasama ,apakah upaya yang dapat dilakukan agar hak dan kewajiban para pihak dalam perjanjian kerjasama operasional menjadi seimbang dan setara, serta upaya-upaya apakah 
yang dapat dilakukan agar hak dan kewajiban para pihak pada badan kerjasamaoperasi/KSO menjadi seimbang dan setara.

\section{B. Metode Penelitian}

Berdasarkan perumusan masalah dan tujuan penelitian, maka metode pendekatan yang digunakan adalah pendekatan yuridis empiris. Pendekatan yuridis adalah suatu pendekatan yang dilakukan atau yang digunakan untuk menjadi acuan dalam menyoroti permasalahan aspek-aspek hukum yang berlaku. Pendekatan yuridis empiris digunakan untuk memberikan gambaran secara kualitatif tentang kedudukan para pihak dalam perjanjian kerjasama operasional pengembangan lahan perumahan dan implikasinya terhadap hak pengelolaan lahan (studi terhadap perjanjian kerjasama operasional pengembangan lahan perumahan antara PT.Ccitra Mitra Properti (Ciputra Grup) dengan PT.Pradipta Ratnapratala)

Pendekatan yuridis diartikan sebagai pendekatan terhadap aturan-aturan hukum yang berhubungan dengan perbuatan hukum mengenai perjanjian khususnya perlindungan hukum terhadap peserta BPJS. Pendekatan empiris dimaksudkan ialah sebagai usaha mendekati masalah yang diteliti dengan sifat hukum yang nyata atau sesuai dengan kenyataan dalam masyarakat.

Dalam melakukan pendekatan yuridis empiris ini, metode yang digunakan adalah metode kualitatif. Metode ini digunakan karena beberapa pertimbangan, yaitu :pertama, menyesuaikan metode ini lebih mudah apabila berhadapan dengan kenyataan ganda; kedua, metode ini menyajikan secara langsung hakekat hubungan antara peneliti dengan responden; ketiga, metode ini lebih peka dan lebih dapat menyesuaikan diri dengan banyak penajaman pengaruh bersama terhadap pola-pola nilai yang dihadapi.

\section{Hasil dan Pembahasan}

\section{Kedudukan Hukum Para Pihak dalam Perjanjian Kerjasama Operasi Pengembangan Lahan Perumahan CitraGarden BMW.}

Pada Perjanjian Kerjasama Operasi Pengembangan Lahan telah diatur bahwa kedudukan PT Pradipta Ratnapratala sebagai pemilik asset dan kedudukan PT Citra Mitra Properti sebagai investor. Sebagaimana kedudukan masing-masing pihak tersebut, peranan pemilik asset dalam Perjanjian Kerjasama Operasi Pengembangan Lahan cendrung pasif dan bersifat menunggu, sedangkan peranan PT Citra Mitra Properti selaku investor cendrung lebih aktif dan bersifat sebagai pelaksana di lapangan. 
Sesuai dengan ketentuan Pasal 7 Perjanjian Kerjasama Operasi Pengembangan Lahan yang mengatur mengenai hak dan kewajiban masing-masing pihak, pada pasal tersebut diatur bahwa pihak PT Pradipta Ratnapratala wajib menyerahkan fisik tanah beserta sertipikat-setipikat tanah dan segala perijinan yang melekat pada tanah kepada pihak kedua yaitu PT Citra Mitra Properti, selain itu secara garis besar pada ketentuan pasal tersebut juga diatur bawah kewajiban pemilik asset yaitu mempersiapkan tanah agar dalam kondisi siap bangun dan bebas gangguan dari pihak lain manapun baik secara langsung maupun tidak langsung, sedangkan kewajiban PT Citra Mitra Properti selaku investor adalah wajib menyiapkan modal kerja serta pengalaman dan kemampuannya dalam bidang properti sehubungan dengan kepentingan pelaksanaan pembangunan proyek. Selanjutnya sebagai tindak lanjut dari dibuatnya Perjanjian Kerjasama Pengembangan Lahan dan sebagai realisasi komitmen pihak PT Pradipta Ratnapratala untuk menyerahkan proses pengembangan pembangunan perumahan Bumi Mutiara Wanayasa dari hulu sampai hilir kepada pihak PT Citra Mitra Properti, maka berdasarkan Perjanjian Kerjasama Operasi Pengembangan Lahan pihak PT Pradita Ratnapratala diwajibkan membuat dan menandatangani akta kuasa menjual.

Akta Kuasa menjual yang wajib dibuat dan ditandatangani oleh PT Pradipta Ratnapratala tersebut pada Badan Kerjasama Operasi/KSO kemudian berfungsi sebagai sebuah dasar hukum yang secara tertulis mengatur mengenai beralihnya hak dan kewenangan untuk membangun, mengelola, menjual maupun untuk melakukan suatu tindakan hukum tertentu atas tanah lahan kerjasama.

Jika ditinjau secara yuridis maka beralihnya hak dan kewenangan tersebut mulai terjadi terhitung sejak tanggal dibuat dan ditandatanganinya akta kuasa menjual, walaupun jika ditinjau dari asas konsensualitas beralihnya hak dan kewenangan pengelolaan dan pengembangan tanah dari PT Pradipta Ratnapratala kepada PT Citra Mitra Properti sudah mulai beralih terhitung sejak terjadinya kesepakatan dan persetujuan dari kedua belah pihak yang ditandai dengan momentum penandatanganan Perjanjian Kerjasama Operasi Pengembangan Lahan.

Hak dan kewenangan yang beralih sebagaimana diatur pada kententuan-ketentuan pada akta kuasa menjual antara lain yaitu hak untuk menjual, melepaskan, membatalkan dan/atau membeli kembali bidang-bidang tanah sebagaimana telah dicantumkan dalam perjanjian. Pada prakteknya, PT Citra Mitra Properti bukan hanya melakukan tindakantindakan hukum tersebut, tetapi juga melakukan segala kegiatan pembangunan, 
pengelolaan serta penjualan sebagaimana lazimnya dilakukan oleh pengembang (developer) yang memiliki lahan tanahnya secara langsung.

Berdasarkan hasil wawancara dengan Ibu Adelia Azela, selaku Legal and Permit Manager pada Citra Pradipta KSO, pada hari Sabtu, tanggal 5 Maret 2016, Salah satu contoh tindakan strategi pemasaran yang dilakukan oleh PT Citra Mitra Properti sehubungan dengan kepentingan penjualan dan agar dapat menarik minat konsumen sebanyak mungkin yaitu dengan menjalin kerjasama dengan bank dan/atau lembaga pembiayaan lain dalam rangka menyediakan fasilitas Kredit Pemilikan Rumah/Tanah $(\mathrm{KPR} / \mathrm{T})$, dengan demikian maka diharapkan konsumen yang membeli unit-unit properti hasil pembangunan proyek bukan hanya dari kalangan masyarakat umum tetapi juga dari para nasabah bank yang menjadi rekanan Badan Kerjasama Operasi/KSO, sehingga dapat tercapai perluasan pangsa pasar dan diversifikasi konsumen.

Mengacu pada peran dan fungsinya pada Badan Kerjasama Operasi/KSO selaku investor yang sepenuhnya melaksanakan kegiatan operasional pengembangan lahan, maka PT Citra Mitra Properti juga berperan aktif bertindak keluar mewakili Badan Kerjasama Operasi/KSO termasuk untuk melakukan ikatan/hubungan hukum dengan pihak ketiga.

Dari kondisi-kondisi sebagaimana dijelaskan tersebut maka dapat disimpulkan bahwa kedudukan PT Citra Mitra Properti selaku penerima kuasa untuk melaksanakan kegiatan operasional pengembangan lahan adalah sangat mendominasi. PT Citra Mitra Properti kemudian memegang kendali terhadap proses pembangunan dari hulu ke hilir, dan pada pelaksanaannya di lapangan PT Citra Mitra Properti melalui Badan Pengelola tidak melibatkan pihak PT Pradipta Ratnapratala dalam memutuskan kebijakan-kebijakan strategis berkaitan dengan pelaksanaan pembangunan/pengembangan lahan, khususnya untuk hal-hal yang berkaitan dengan biaya-biaya yang dikeluarkan sehubungan dengan kegiatan operasional pengembangan lahan.

\section{Implikasi Dominasi PT Citra Mitra Properti pada Badan Kerjasama Operasi/KSO terhadap Hak Pengelolaan Lahan.}

Setelah dibuat dan ditandatanganinya Akta Kuasa Menjual oleh PT Pradipta Ratnapratala yang ditujukan kepada PT Citra Mitra Properti maka secara yuridis telah terjadi pengalihan kewenangan untuk melakukan beberapa tindakan hukum terhadap tanah lahan kerjasama dari PT Pradipta Ratnapratala kepada PT Citra Mitra Properti, dimana sebelumnya kewenangan tersebut milik PT Pradipta Ratnapratala selaku pemilik tanah lahan kerjasama, 
tetapi dengan dibuat dan ditandatanganinya Akta Kuasa Menjual tersebut terdapat hal yang perlu digarisbawahi yaitu bahwa dengan beralihnya kewenangan untuk melakukan beberapa tindakan hukum terhadap tanah lahan kerjasama tersebut tidak berarti bahwa hak kepemilikan tanah beralih kepada PT Citra Mitra Properti, karena di dalam Akta Kuasa Menjual kewenangan yang diberikan kepada PT Citra Mitra Properti diatur dan dibatasi, pembatasan kewenangan berdasarkan Akta Kuasa Menjual ini antara lain yaitu mengembangkan tanah lahan kerjasama, mengelola dan menjual hasil pelaksanaan proyek pembangunan lahan kerjasama.

Hasil wawancara dengan Bapak Tanta Sugianta, selaku Senior Legal and Permit Manager pada Ciputra Grup Sub Holding 1, pada hari Kamis, tanggal 10 Maret 2016 menyatakan bahwa Implikasi paling konkrit yang kemudian terjadi sebagai konsekuensi dibuat dan ditandatanganinya Akta Kuasa Menjual diantaranya adalah sebagai berikut:

1) Hilangnya kewenangan PT Pradipta Ratnapratala untuk mengelola lahan tanahnya sendiriPT Pradipta Ratnapratala kehilangan hak dan kewenangan untuk mengelola lahan tanah miliknya dengan cara serta usahanya sendiri dan untuk melakukan penjualan terhadap hasil pengembangan tanah tersebut, selain itu terhitung sejak Perjanjian Kerjasama Operasi Pengembangan Lahan dibuat dan ditandatangani maka pihak PT Pradiptra Ratnapratala tidak dapat lagi menjual dan/atau mengalihkan lahan tanah miliknya tersebut baik secara sebagian maupun seluruhnya kepada pihak lain manapun, walaupun hal tersebut dilaksanakan dengan terlebih dahulu memintakan persetujuan dari pihak PT Citra Mitra Properti.

2) PT Pradipta Ratnapratala tidak memiliki kewenangan untuk menentukan besarnya biaya operasional yang dikeluarkan untuk kegiatan pengembangan lahanPada kegiatan operasional pengembangan lahan yang dilakukan secara berkesinambungan, PT Pradipta Ratnapratala tidak memiliki fungsi kontrol langsung terhadap arus kas Badan Pengelola, karena selaku pemilik asset yang kedudukannya cendrung pasif pada Badan Kerjasama, yang dapat dilakukan oleh PT Pradipta Ratnapratala untuk mengkontrol arus kas hanya sebatas pada laporan keuangan yang dilaporkan oleh direksi PT Citra Mitra Properti, dimana laporan keuangan tersebut pastilah merupakan rangkuman yang bukan berisi detail pengeluaran, sehingga PT Pradipta Ratnapratala tidak dapat memberikan masukan untuk melakukan penghematan pada biaya operasional kegiatan pengembangan lahan.Hal tersebut tentu saja akan berdampak pada laba yang diperoleh oleh Badan Kerjasama, dimana apabila biaya operasional dapat ditekan dengan 
sehemat mungkin maka kemungkinan bahwa laba yang akan diperoleh oleh Badan Kerjasama akan semakin besar, dan begitu pula sebaliknya. Penghematan yang dapat dilakukan biasanya adalah mengenai pembelian alat-alat investaris Badan Kerjasama dan pengeluaran biaya perjalanan dinas para anggota Badan Pengelola.

3) Hilangnya figur PT Pradipta Ratnapratala sebagai pemilik dan pengembang perumahan Bumi Mutiara WanayasaSebagaimana telah dijelaskan sebelumnya bahwa dengan dibuat dan ditandatanganinya Perjanjian Kerjasama Operasi/KSO Pengembangan Lahan antara PT Pradipta Ratnapratala dengan PT Citra Mitra Properti maka kemudian terjadi penggantian merek dagang proyek perumahan Bumi Mutiara Wanayasa, dimana merek dagang yang baru lebih menonjolkan citra Ciputra Grup daripada menonjolkan merek dagang yang sudah ada sebelumnya. Dengan terjadinya hal tersebut maka image baru yang kemudian muncul di mata masyarakat adalah bahwa pembangunan dan pegembangan proyek perumahan Bumi Mutiara Wanayasa yang sebelumnya dilaksanakan oleh PT Pradipta Ratnapratala sudah diambil alih oleh Ciputra Grup. Hal tersebut kemudian terlihat semakin tegas saat kata Bumi Mutiara Wanayasa pada cara penulisan merek dagang yang baru disingkat hanya menjadi BMW saja, dimana selengkapnya ditulis dengan kata CitraGarden BMW, dengan warna dan format standar wajib perusahaan-perusahaan afiliasi Ciputra Grup. Dampak baik yang kemudian muncul setelah hal tersebut terjadi adalah bertambah banyaknya masyarakat yang kemudian datang untuk sekedar mengetahui lebih jauh mengenai unit-unit rumah dan toko yang dipasarkan di proyek perumahan CitraGarden BMW atau bahkan membeli unit-unit rumah dan toko tersebut, karena sebagaimana telah dijelaskan sebelumnya juga bahwa untuk merek dagang tertentu seringkali sudah memiliki pangsa pasarnya sendiri dari kalangan masyarakat tertentu.Perlu juga disampaikan bahwa sesuai sebagaimana keterangan yang telah diberikan oleh salah satu karyawan PT Citra Mitra Properti melalui wawancara, digantinya merek dagang tersebut yang kemudian juga dilengkapi dengan logo, diatur lebih lanjut secara lebih detail pada Perjanjian Lisensi Logo dan Merek, dimana dengan dibuat dan ditandatanganinya Perjanjian Lisensi Logo dan Merek tersebut selanjutnya menimbulkan kewajiban untuk membayar royalty kepada salah satu perusahaan afiliasi Ciputra Grup selaku pemegang merek dagang, dimana pembayaran royalty tersebut dipotong dari laba yang masuk/diperoleh oleh Badan Pengelola. 


\section{Upaya-upaya yang dapat Dilakukan agar Hak dan Kewajiban Para Pihak pada Badan Kerjasama Operasi/KSO menjadi Seimbang dan Setara.}

Apabila ditinjau dari efisiensi dan efektivitas pelaksanaan kegiatan bisnis maka dapat disimpulkan bahwa cara pendirian dan pembubaran sebuah Badan Kerjasama Operasi/KSO dilakukan secara lebih singkat sehingga dapat dikatakan bahwa cara pendiriannya tersebut lebih efektif dan efisien jika dibandingkan dengan cara mendirikan badan usaha patungan berbentuk badan hukum seperti Perseroan Terbatas Joint Venture (PT JV), kondisi ini tentu saja sangat menguntungkan bagi para pelaku usaha, karena agar konsep sebuah badan usaha berupa Kerjasama Operasi/KSO ini dapat terus diaplikasikan pada kegiatan usaha para pelaku usaha maka sebaiknya hal-hal yang dilihat sebagai kekurangan pada konsep Kerjasama Operasi/KSO ini dapat dievaluasi dari waktu ke waktu dan untuk selanjutnya dilakukan perbaikan agar dapat diperoleh sebuah gambaran ideal mengenai pendirian serta pelaksanaan sebuah badan Kerjasama Operasi yang nantinya dapat menjadi acuan tata laksana mengenai keberadaan Kerjasama Operasi/KSO khususnya di Indonesia.

Beberapa hal yang dapat dilakukan bagi para pihak yang terlibat pada Citra Pradipta KSO ini agar dapat tercapainya sebuah kesimbangan kedudukan pada badan kerjasama sehingga terciptalah sebuah kerjasama usaha yang baik dan harmonis dan berlangsung untuk jangka waktu lama, antara lain sebagai berikut :

1. Penerapan Asas-Asas Perjanjian Pada Perjanjian Kerjasama Operasi/KSO Pengembangan Lahan Untuk Melindungi Kedudukan Hukum Para Pihak

a. Penerapan Asas Kebebasan Berkontrak Dalam Perjanjian KerjasamaPengembangan Lahan

Asas itikad baik dapat disimpulkan dari ketentuan Pasal 1338 ayat (3) KUHPerdata, yang berbunyi: "suatu perjanjian harus dilaksanakan dengan itikad baik." Itikad baik menurut pasal tersebut adalah bahwa pelaksanaan perjanjian itu harus berjalan dengan mengindahkan norma-norma kepatutan dan kesusilaan. Mengenai apa yang dimaksud dengan kepatutan dan kesusilaan, undang-undang tidak memberikan rumusannya. Oleh karena itu, tidak ada ketetapan batasan mengenai pengertian istilah tersebut.Berdasarkan arti kedua kata tersebut, kiranya dapat digambarkan bahwa kepatutan dan kesusilaan itu sebagai nilai yang patut, pantas, layak, sesuai, cocok, sopan dan beradab, 
sebagaimana sama-sama dikehendaki oleh masing-masing pihak yang membuat perjanjian.

Dengandimasukkannya itikad baik pada pelaksanaan perjanjian berarti juga bahwa kita harus menafsirkan perjanjian itu berdasarkan keadilan dan kepatutan. Dalam KUHPerdata, kepatutan (asas kepatutan) dituangkan dalam Pasal 1339 KUHPerdata yang menyatakan bahwa perjanjian tidak hanya mengikat untuk halhal yang dengan tegas dinyatakan didalamnya, tetapi juga untuk segala sesuatu yang menurut kepatutan, kebiasaan atau undang-undang.

Berdasarkan ketentuan Pasal 1338 ayat (3) KUHPerdata, apabila terjadi selisih pendapat tentang pelaksanaan perjanjian dengan itikad baik (kepatutan dan kesusilaan), maka hakim diberi wewenang oleh undang-undang untuk mengawasi dan menilai pelaksanaan perjanjian, apakah ada pelanggaran terhadap normanorma kepatutan dan kesusilaan itu. Hal ini berarti bahwa hakim berwenang untuk menyimpang dari isi perjanjian menurut kata-katanya, apabila pelaksanaan perjanjian menurut kata-katanya akan bertentangan dengan itikad baik (apabila pelaksanaan menurut norma-norma kepatutan dan kesusilaan itulah yang dipandang adil), karena tujuan hukum adalah untuk menjamin kepastian (ketertiban) dan menciptakan keadilan.

Asas kebebasan berkontrak menurut hukum perjanjian Indonesia meliputi ruang lingkup sebagai berikut ${ }^{1}$.

i. Kebebasan untuk membuat atau tidak membuatperjanjian.

ii. Kebebasan untuk memilih pihak dengan siapa ia inginmembuat perjanjian.

iii. Kebebasan untuk menentukan atau memilih causa dari perjanjian yang akan dibuatnya.

iv. Kebebasan untuk menentukan objek perjanjian.

v. Kebebasan untuk menentukan bentuk suatu perjanjian.

vi. Kebebasan untuk menerima atau menyimpangi ketentuan undangundang yang bersifat opsional (aanvullend, optional).

b. Penerapan Asas Kepastian Hukum Dalam Perjanjian Kerjasama Operasi/KSO Pengembangan Lahan.

Pengertian Asas Kepastian Hukum adalah suatu jaminan bahwa suatu hukum harus dijalankan dengan cara yang baik atau tepat. Kepastian pada intinya

\footnotetext{
${ }^{1}$ Budiono Herlien, Kebebasan Berkontrak Yang Seimbang Dalam Suatu Perjanjian (Jakarta: Media Notariat, 1993).
} 
merupakan tujuan utama dari dibentuk dan dibuatnya hukum. Apabila hukum dibuat tanpa ada kepastian hukum maka hukum akan kehilangan jati diri serta maknanya. Jika hukum tidak memiliki jati diri maka hukum tidak lagi digunakan sebagai pedoman perilaku setiap orang ${ }^{2}$.

Apabila hal tersebut terjadi pada pelaksanaan Perjanjian Kerjasama Operasional/KSO Pengembangan Lahan maka hal ini sangat potensial menimbulkan konflik diantara para pihak yang terlibat dalam Perjanjian Kerjasama Operasi/KSO Pengembangan Lahan dan bukan hal yang tidak mungkin jika hal ini juga dapat berdampak pada munculnya konflik dengan pihak lain yang berkaitan dengan Badan Kerjasama Operasi/KSO, karena dengan dibuat dan ditandatanganinya Perjanjian Kerjasama Operasi/KSO Pengembangan Lahan maka berarti sudah dilakukan berbagai kegiatan pembangunan yang sifatnya melibatkan pihak lain seperti kontraktor, pemasok (supplier) dan konsumen.

Dengan demikian maka fungsi dan tugas utama dari diterapkannya Asas Kepastian Hukum yaitu untuk menjamin kedudukan masing-masing pihak yang terlibat dalam Perjanjian Kerjasama Operasi/KSO Pengembangan Lahan dan juga pihak-pihak lain yang ikut serta terlibat dalam pelaksanaan kegiatan pengembangan lahan baik secara langsung maupun secara tidak langsung, dengan demikian terdapat batasan yang jelas antara hak dan kewajiban masing-masing pihak dan diharapkan tidak ada intervensi antara hak dan kewajiban salah satu pihak dengan hak dan kewajiban pihak lainnya.

2. Melibatkan PT Pradipta Ratnapratala Pada Kegiatan Operasional Pengembangan Lahan

Demi tercapainya sebuah kedudukan hukum yang setara dan seimbang sesuai dengan besarnya modal yang dibawa dan/atau dimasukan oleh masing-masing pihak pada Badan Kerjasama Operasi/KSO Pengembangan Lahan, sebaiknya pada pelaksanaan kegiatan operasional pengembangan lahan pihak PT Citra Mitra Properti sebagai pihak yang berwenang penuh terhadap Badan Pegelola juga melibatkan PT Pradipta Ratnapratala. Apabila hal tersebut dilaksanakan maka hal tersebut merupakan sebuah itikad baik (good will) dari pihak PT Citra Mitra Properti kepada pihak PT Pradipta Ratnapratala, dan dapat semakin memperkecil timpangnya kedudukan diantara para pihak yang terlibat pada Perjanjian Kerjasama Operasi/KSO Pengembangan Lahan.

\footnotetext{
2‘Www.pengertianmenurutparaahli.com/pengertian-Asas-Kepastian-Hukum’, 2016.
} 
Fungsi dan tujuan dari melibatkan PT Pradipta Ratnapratala ke dalam kegiatan operasional pengembangan lahan yaitu untuk menjalankan fungsi kontrol terhadap arus kas, dengan memperhatikan dan mempertimbangkan jika semakin kecil biaya operasional yang dikeluarkan untuk kegiatan pengembangan lahan maka harapan untuk memperoleh laba yang lebih banyak semakin besar. Hal ini dapat diaplikasikan dengan tetap berpegang pada fungsi dan kedudukan masing-masing pihak selaku pemilik asset dan selaku penyedia modal (investor), dimana pasti terdapat hal-hal dan pengalamanpengalaman yang bersifat krusial yang dimiliki oleh PT Citra Mitra Properti selaku pengembang yang tidak dimiliki oleh PT Pradipta Ratnapratala sehingga untuk hal-hal tertentu yang sifatnya teknis kegiatan pengembangan lahan pihak PT Pradipta Ratnapratala sebaiknya tidak turut serta mengambil keputusan yang dapat berdampak pada terjadinya intervensi.

Dengan diikut-sertakannya pihak PT Pradipta Ratnapratala pada kegiatan operasional pengembangan lahan melalui Badan Pengelola maka hal tersebut dapat menjadi penilaian bahwa PT Citra Mitra Properti telah menerapkan prinsip keterbukaan dan transparansi sebagai realisasi penerapan good corporate governance pada Badan Kerjasama Operasi/KSO. Asas transparansi ini merupakan salah satu unsur yang menopang terwujudnya good and clean governance ${ }^{3}$.

Konsep transparansi didefinisikan oleh Loila Lalolo Krina sebagai prinsip yang menjamin akses atau kebebasan bagi setiap orang untuk memperoleh informasi tentang penyelenggaraan pemerintahan, yakni informasi tentang kebijakan, proses pembuatan dan pelaksanaannya, serta hasil-hasil yang dicapai ${ }^{4}$.

Untuk dapat tercapainya keseimbangan dan kesetaraan dalam sebuah pelaksanaan Perjanjian Kerjasama Operasi/KSO Pengembangan Lahan, hal-hal yang dapat dilakukan biasanya bersifat preventif atau pencegahan, yaitu salah satunya dengan cara mengatur mengenai ketentuan tersebut dalam perjanjian kerjasama yang merupakan titik awal dimulainya seluruh pelaksanaan kegiatan kerjasama pengembangan lahan. Apabila halhal tersebut tidak diberitahukan dan diperjanjikan sebelumnya dalam perjanjian, maka dikemudian hari ketika proyek dan kegiatan operasional sudah mulai dilaksanakan akan rentan terhadap terjadinya konflik. Hal tersebut disebabkan karena hak dan kewajiban para pihak tidak diatur dan ditegaskan sebelumnya secara terinci dalam perjanjian.

\footnotetext{
${ }^{3}$ Ambar Teguh Sulistiyani, Memahami Good Governance (Jakarta: PT. Gava Media, 2000).

${ }^{4}$ Loila Lalolo Krina P, 'Indikator Dan Alat Ukur Akuntanbilitas, Transparansi Dan Partisipasi' (Jakarta: Sekretariat Good Public Governance Badan Perencanaan Pembangunan Nasional).
} 
Tindakan preventif lain yang dapat dilakukan adalah dengan membuat bagan mengenai struktur organisasi Badan Pengelola, dimana pihak PT Pradipta Ratnapratala selaku pemilik asset juga diberikan kewenangan untuk ikut serta menjadi anggota personil Badan Pengelola dan/atau menunjuk beberapa personil yang ditempatkan pada struktur organisasi Badan Pengelola, walaupun misalnya kewenangan yang diberikan kepada PT Pradipta Ratnapratala ini tidak sedominan sebagaimana kewenangan yang dimiliki oleh PT Citra Mitra Properti. Contohnya, bagian keuangan Badan Pengelola hanya terdiri dari 5 (lima) personil yang fungsinya terdiri dari administrator sampai dengan manager, lalu penunjukan dan/atau penempatan bagian keuangan Badan Pengelola tersebut dilaksanakan dengan komposisi 3 (tiga) orang ditunjuk dan/atau ditempatkan oleh investor dan 2 (dua) orang lainnya ditunjuk dan/atau ditempatkan oleh pemilik asset, dengan ketentuan bahwa posisi manager yang memiliki kewenangan untuk memutuskan wajib ditunjuk dan/atau ditempatkan oleh pihak investor dengan pertimbangan bahwa investor adalah pihak yang menguasai lapangan serta sudah berpengalaman dalam melaksanakan teknis proyek pengembangan lahan sehingga pihak investor diharapkan memiliki keterampilan dan pengetahuan (knowledge) yang lebih baik daripada pemilik asset.

Pada kasus Perjanjian Kerjasama Operasi/KSO Pengembangan Lahan ini salah satu upaya yang dapat dilakukan untuk menjaga keseimbangan dan kesetaraan kedudukan para pihak adalah dengan melibatkan pihak PT Pradipta Ratnapratala dalam penandatanganan Surat Penunjukan/Pengangkatan penanggung jawab Badan Pengelola, walaupun sesuai dengan ketentuan yang telah diatur dalam Perjanjian Kerjasama Operasi/KSO Pengembangan Lahan bahwa penanggung jawab Badan Pengelola adalah karyawan pihak PT Citra Mitra Properti, tetapi apabila dalam SuratPenunjukan/Pengangkatannya juga tercantum tanda-tangan dari pihak PT Pradipta Ratnapratala maka hal tersebut sudah dapat menjadi salah satu cerminan kesetaraan kedudukan diantara para pihak, yaitu bahwa penunjukan/pengangkatan Penanggung Jawab Badan Pengelola juga diketahui dan disetujui oleh pihak PT Pradipta Ratnapratala selaku pemilik aset.

\section{Simpulan}

Kedudukan para pihak dalam perjanjian kerjasama operasional pengembangan lahan yaitu bahwa pihak PT Pradipta Ratnapratala selaku pemegang hak atas lahan 
kerjasama/selaku pemilik asset adalah cendrung pasif yang tidak terlibat dalam kegiatan operasional sehari-hari proyek pengembangan lahan. Sifatnya selaku pihak pemilik asset adalah menunggu pembagian keuntungan hasil penjualan/pelaksanaan proyek pengembangan lahan, dan kontrol yang dapat dilakukan oleh PT Pradipta Ratnapratala terhadap arus kas Badan Pengelola hanya dapat dilaksanakan melalui laporan keuangan yang diberikan oleh pihak direksi PT Citra Mitra Properti secara berkala.

Hal tersebut kemudian berdampak pada tidak adanya kewenangan pihak PT Pradipta Ratnapratala untuk ikut serta memutuskan jumlah pengeluaran yang seharusnya dikeluarkan atau seharusnya tidak dikeluarkan oleh Badan Pengelola, dimana hal tersebut dapat berdampak secara signifikan pada pembagian keuntungan bagi para pihak pada akhir periode tahun buku.

Timpangnya kedudukan para pihak dalam Perjanjian Kerjasama Operasi/KSO Pengembangan Lahan terjadi karena pihak PT Pradipta Ratnapratala selaku pemilik asset tidak diikut-sertakan pada kegiatan operasional pengembangan lahan dan juga tidak memiliki kewenangan dalam memutuskan dan/atau menempatkan personil-personil yang ditempatkan pada Badan Pengelola.

Upaya-upaya yang dapat dilakukan untuk meminimalisir terjadinya ketidak-seimbangan dan/atau ketidaksetaraan kedudukan diantara para pihak yang terlibat dalam perjanjian kerjasama pengembangan lahan ini yaitu dengan memperbaiki dan/atau menambahkan klausul-klausul dalam perjanjian, khususnya yang mengatur mengenai hak dan kewajiban serta kewenangan masing-masing pihak. Selain itu sebaiknya pihak PT Pradipta Ratnapratala selaku pemilik asset diberikan kewenangan untuk ikut serta dapat menempatkan dan/atau menunjuk personil-personil anggota Badan Pengelola.

\section{DAFTAR PUSTAKA}

Herlien, Budiono. (1993). Kebebasan Berkontrak Yang Seimbang Dalam Suatu Perjanjian. Jakarta: Media Notariat.

Krina P, Loila Lalolo. 'Indikator Dan Alat Ukur Akuntanbilitas, Transparansi Dan Partisipasi' . Jakarta: Sekretariat Good Public Governance Badan Perencanaan Pembangunan Nasional.

Sulistiyani, Ambar Teguh. (2000). Memahami Good Governance. Jakarta: PT. Gava Media.

'www.pengertianmenurutparaahli.com/pengertian-Asas-Kepastian-Hukum', 2016 
